\title{
ИЗУЧЕНИЕ НОВЕИШИХ ОТЛОЖЕНИЙ ПРИБАЛТИКИ И БЕЛОРУССИИ ИЗОТОПНО-ГЕОХИМИЧЕСКИМИ МЕТОДАМИ
}

\author{
I.M. PUNNING. ISOTOOP-GEOKEEMILISED MEETODID JA NENDE KASUTAMINE KVATER- \\ NAARSETE SETETE UURIMISEKS BALTIKUMIS JA VALGEVENES \\ I.-M. PUNNING. THE ISOTOPIC-GEOCHEMICAL METHODS AND THEIR USE FOR STUDYING \\ QUATERNARY DEPOSITS IN THE BALTIC AND BYELORUSSIAN REGIONS
}

Изотопные методы используются в геологии уже несколько десятилетий, а начиная с 50-х годов получили широкое применение для изучения событий, происходивших в плейстоцене и голоцене. Благодаря относительно несложной методике исследования некоторые из них, и в первую очередь радиоуглеродный метод абсолютного летоисчисления, завоевали широкое признание. Резко возросло количество датиоовок и, как естественное следствие, число несовпадающих данных. Ошибки в определении возраста по $\mathrm{C}^{14}$ могут быть обусловлены как несоблюдением основных допущений метода, так и отклонениями от методики, неправильным использованием эталонов и т. д. В целях дальнейшей координации всех изотопно-геохимических работ бюро Прибалтийско-Белорусской секции провело в декабре 1972 г. в Таллине соответствующий семинар.

К сожалению, в настоящее время в разных учреждениях региона из числа изотопных методов внедрен в основном только радиоуглеродный метод датирования. Действуют четыре радиоуглеродные лаборатории, главной целью которых является измерение содержания природного радиоуглерода в геологических и археологических объектах.

В течение длительного времени успешно работает лаборатория при Институте зоологии и ботаники АН ЭССР (г. Тарту), в которой проведено свыше 500 определений. Недавно начались серийные определения возраста при Институте геологии АН ЭССР (г. Таллин), где датировано более 80 объектов. В Латвии действует радиоуглеродная лаборатория при Всесоюзном научно-исследовательском институте морской геологии и геофизики (г. Рига), где определен возраст около 50 образцов. В Литовском научно-исследовательском геологоразведочном институте (г. Вильнюс) выполнено около 70 радиоуглеродных анализов. В стадии организации находятся радиоуглеродные лаборатории при Институте ботаники $\mathrm{AH}$ ЛитССР и при Институте геохимии и геофизики АН БССР.

Очень интересные исследования проводятся в Институте физики и математики АН ЛитССР, где изучается вариация ряда изотопов (Be ${ }^{7}$, $\mathrm{Na}^{22}, \mathrm{C}^{14}, \mathrm{P}^{33}, \mathrm{~S}^{35}$ и др.) в атмосфере и процессы генерации. Эти работы представляют особый интерес в связи с изучением законов динамики изотопов в атмосфере и времени их пребывания в различных частях природного резервуара.

Количество радиоуглеродных датировок геологических объектов, выполненных по отдельным республикам региона, следующее: Белоруссия 60 , Литва -60 , Латвия -70 , Эстония -250 , или суммарно - около 
440 определений. Это довольно большое количество и, учитывая относительно небольшую территорию этих республик, можно сказать, что они являются наиболее детально изученным регионом (в смысле радиоуглеродного датирования) во всем Советском Союзе. На основе проведенных анализов разработаны детальные геохронологические шкалы голоцена для территорий Эстонии и Литвы, дана геохронологическая интерпретация деградации ледника последнего оледенения, представлены геохроно логические схемы верхнего плейстоцена, разработана геохронология раз вития древнебалтийских водоемов голоцена на территории Эстонии и отчасти Латвии.

Все радиоуглеродные лаборатории успешно занимаются вопросами повышения надежности счетной системы измерения активности $\mathrm{C}^{14}$. Достигнуты неплохие результаты, позволяющие получить даты, статистическое отклонение которых приближается к теоретической гранище, т. е. к ошибке определения периода полураспада $\mathrm{C}^{14}$. Однако надо иметь в виду, что эта ошибка заключается не только в статистическом характере распада $C^{14}$ и нестабильности аппаратуры. Незначительная величина статистической ошибки еще далеко не гарантирует достоверности результатов, так как она не включает отклонений, обусловленных возможными процессами изотопных смещений как в природных условиях, так и в ходе приготовления счетного препарата, загрязнением образца примесями н несостоятельностью основных допущений самого метода.

Иногда и очень тщательно проведенные исследования в разных лабо раториях не могут дать истинного времени происхождения каких-либо геологических событий, так как к настоящему времени можно считать доказаңным, что одно из основных допущений радиоуглеродного метода - постоянство концентрации $\mathrm{C}^{14}$ в атмосфере верно только в первом приближении. Тщательно проведенные исследования многими лабораториями, в основном зарубежными, показывают, что скорость генерации $\mathrm{C}^{14}$ за последние 10000 лет изменилась в довольно значительных пределах. Этот вопрос широко обсуждался как на 12-м Нобелевском симпозиуме «Вариации радиоуглерода и абсолютная хронология», так и на 24-м международном геологическом конгрессе.

Основными причинами отклонений являются (Stuivier, 1970; Дэмон, Уоллик, 1972 и др.) изменения магнитного момента Земли, гелиомагнитная модуляция потока космических лучей и изменение климата. Все эти факторы вызывали изменения скорости образования $\mathrm{C}^{14}$. и меняли содержание и время пребывания $\mathrm{C}^{14}$ в различных углеродных резервуарах. Для последних 8000-9000 лет теперь имеются довольно хорошо совпадающие данные, показывающие, что изменения концентрации $\mathrm{C}^{14}$ варьировались в довольно широких пределах - до десяти и более процентов, составляя разницу между радиоуглеродным и истинным возрастом больше чем в 800 лет. Уже созданы графики, связывающие радиоуглеродный и истинный возрасты на основе определения концентрации $\mathrm{C}^{14}$ в древесных кольцах (Fergusson, 1970; Suess, 1970). Убедительно доказаны эти данные и в работе M. Стуйвье (Stuivier, 1970), который изучал скорости седиментации ряда озер в разных частях Земного шара и определял $\mathrm{C}^{14}$ в донных отложениях. Сравнивая радиоуглеродные и варвометрические возрасты, $M$. Стуйвье предлагает следующие поправочные коэффициенты: 1. Интервал $0-2500$ календарных лет: $1 \mathrm{C}^{14}$ год=1 действительному году.

2. Интервал $2500-5500$ календарных лет: $1 \mathrm{C}^{14}$ год $=1,26$ действительного года.

3. Интервал 5500-10000 календарных лет : $1 \mathrm{C}^{14}$ год=1,03 варвометрического года, причем этот интервал можно разделить на два перио- 
да $-7100-8300$ лет $: 1 \mathrm{C}^{14}$ год $=0,8$ и $8300-9500: \mathrm{C}^{14}$ год $=1,4$ варвометрического года. К сожалению, пока отсутствуют достоверные данные для периода свыше 10000 лет.

Вторым неясным моментом является величина периода полураспада $\mathrm{C}^{14}$. В настоящий момент разные лаборатории используют разные величины периода полураспада: 5570 лет и, более вероятный, 5730 лет. Если исходить из цифры 5730 лет, то надо результаты, полученные при использовании величины 5570 лет, умножить на 1,03. В литературе можно встретить три величины радиоуглеродного возраста: 1) конвенциональный (такие данные публикуют все лаборатории Советского Союза); 2) корректированный (используется период полураспада в 5730 лет) и 3) «истинный» (период полураспада в 5730 лет и коррекция с величиной, полученной при изучении вариации $\mathrm{C}^{14}$ в годичных кольцах древесины).

Все это еще раз подчеркивает важность и своевременность применения и развития других изотопно-геохимических методов как для палеоклиматологических, так и геохронологических реконструкций. В первую очередь следует больше уделять внимания изучению донных отложений Балтийского моря с широким использованием масс-спектрометрического анализа, который незаменим при исследовании изменений изотопного равновесия стабильных изотопов углерода как в природе, так и в процессе лабораторной обработки образцов. Кроме того, надо внедрять методы определения возраста по изотопам семейств урана и актиноурана.

В последние годы во всем мире проводятся обширные работы по использованию и усовершенствованию термолюминесцентного и палеомагнитного методов изучения новейших отложений. Возможно, что термолюминесцентный метод, кроме классических исследований лессовых пород, применим и для изучения некоторых водно-ледниковых отложений.

Привлечение бо́льшего количества методов исследования новейших отложений сделает наши геохронологические шкалы более достоверными и, что особенно важно, значительно расширит их возрастные рамки.

\section{ЛИТЕРАТ У РА}

Д э м о н П. Э., У о л л и к Э. 1972. Изменения конщентрации радиоуглерода в атмосфере за последние восемь тысяч лет. В сб.: Очерки современной геохимии и аналитической химии. М.

Fergusson G. J. 1970. Dendrochronology of bristlecone pine, Pinus aristata. Establishment of a 7484 year chronology in the White Mountains of Eastern-central California, U.S.A. Radiocarbon Variations and Absolute Chronology. Proc. of the Twelfth Nobel Symposium held at the Inst. of Physics at Uppsala University.

Stuivier M. 1970. Long-term $C^{14}$ variations. Radiocarbon Variations and Absolute Chronology. Proc. of the Twelfth Nobel Symposilim held at the Inst. of Physics at Uppsala University.

S ues s H. E. 1970. Bristlecone-pine calibration of the radiocarbon time-scale 5200 B.C. to present. Radiocarbon Variations and Absolute Chronology. Proc. of the Twelfth Nobel Symposium held at the Inst. of Physics at Uppsala University. 